\title{
Environmental justice and the expanding geography of wind power conflicts
}

Sofia Avila

Institute of Environmental Science and Technology (ICTA)

Autonomous University of Barcelona (UAB)

E-mail: acalerosofia@gmail.com

This is a post-print version. For printed version click here

Please cite as:

Avila, S (2018) Environmental justice and the expanding geography of wind power conflicts, Sustainability Science, 13: 599. https://doi.org/10.1007/s11625-018-0547-4

\begin{abstract}
Wind power is expanding globally. Simultaneously, a growing number of conflicts against large-scale wind farms are emerging in multiple locations around the world. As these processes occur, new questions arise on how electricity from wind is being generated, how such energy is flowing within societies, and how these production-flows are being shaped by specific power structures. The present paper explores the expanding geography of wind energy conflicts by analyzing 20 case-studies from across the Americas, Africa, Asia and Europe. Based on the Environmental Justice Atlas database, it reflects on how land pressures and patterns of uneven development emerge as two features of the current expansion of wind farms. Following a relational analysis, these patterns are examined to interpret the plural instances of opposition emerging throughout the rural spaces of the world. The article argues that previously unexplored forms of collective action are expanding
\end{abstract}


the scope and content of the "wind energy debate". In addition to the claims of "landscape" and "wildlife protection" addressed by the existing literature, this study sheds light on the rural/peripheral contexts where opposition emerges through the defense of indigenous territories, local livelihoods and community development projects. The study contends that these "emerging storylines" embrace an environmental justice perspective, when challenging the socially unequal and geographically uneven patterns reproduced by the ecological modernization paradigm. From this lens, cases of local opposition are not interpreted as selfish forces blocking a low-carbon transition, but instead, are understood as political instances that enable a wider discussion about the ways such processes should take place.

\title{
Keywords
}

\author{
Wind energy \\ Land pressures \\ Uneven development \\ Ecological modernization \\ Conservationism \\ Environmental justice
}

\section{Introduction}

In the context of climate change and energy concerns, the need to shift towards a low-carbon energy system has become one of the central challenges for achieving sustainability. The means to achieve these goals and the ends of such a transition is, however, a contested space disputed by divergent interests, values and prospects of future (Bradley and Herdén 2014). The growing number of conflicts emerging against renewable energy projects reflects an important part of such tensions, offering an opportunity to address the multiple voices and power rearrangements that have emerged towards this major societal transformation. This paper focuses on the case of wind power and introduces an inventory of 20 new cases of conflicts emerging in different sociogeographical contexts of Africa, the Americas, Asia and Europe. 
Much of the literature addressing social attitudes against wind power since the late 1980s has given central attention to assessing the adequacy of NIMBY interpretations of social opposition and the consequent policy measures to improve acceptance of projects (Thayer and Hansen 1991; Wolsink 2000; Smith and Klick 2007; Petrova 2013). With a geographical focus on the most developed countries, these studies tend to share a particular interest in closing the "social gap" that still blocks the growth of the wind energy industry (Agterbosch et al. 2007; Brown 2011; Bell et al. 2013). New perspectives are, however, slowly moving beyond this problemsolution perspective in order to address the dominant storylines supporting the rapid expansion of large-scale facilities, and to systematize the heterogeneous claims coming from different social groups (Ellis et al. 2006; Szarka 2007; Jessup 2010).

The wind power debate that draws from such literature illustrates how controversies generally splits into a dual tension between those who support the rapid expansion of industrial wind power as a means to solve the energyclimate crisis (generally framed as part of the ecological modernization paradigm), and those who are concerned with the protection of local landscapes and environmentally sensitive places (generally framed within environmental conservation narratives). In contrast to the former academic convention, these new insights place the wind energy expansion as an actual political issue, shaped by different worldviews, interests and values. But while such emerging literature provides rich insights into outlining the wind energy debate, both a geographical and theoretical expansion is needed. Firstly, because wind power investments are rapidly covering new locations around the world (particularly in the Global South). Secondly, because the land uses, power structures and potentially affected populations of these new locations might differ significantly from those analyzed by the existing literature.

In an attempt to cover these unexplored spaces, the inventory of conflicts presented here is taken as an empirical basis to analyze two relational issues: (i) what are the configurations of the current wind power expansion; and (ii) how such expansion is expressed and contested in different socio-geographical contexts. By using the Environmental Justice Atlas platform as the guiding methodology of research, the present article offers 
systematical evidence of the land pressures and patterns of uneven development deriving from the global expansion of large-scale wind power projects. Such patterns are, in turn, used to interpret the increasing instances of contestation along the rural spaces of the world. In addition to the imaginaries of "landscape" and "wildlife protection" addressed by existing literature, the present article sheds light on the rural contexts where new narratives emerge throughout the defense of territories, livelihoods and community-based development projects. As I will argue, these "emerging storylines" embrace an environmental justice perspective, when challenging the socially unequal and geographically uneven patterns derived from the ecological modernization paradigm.

The combination of these processes suggests a changing path in the scope and content of the wind energy debate. In particular, these new insights contribute to place the wind energy expansion as embedded in the politics of truth, rule and accumulation (Scoones 2016) of the low-carbon transition; while opening possibilities of discussing alternative energy futures. The analytical approach of this research combines cross-disciplinary literature of critical human geography, political ecology and environmental justice theories. It takes critical perspectives over energy development (Harrison 2013; McCarthy 2015; Huber 2015), and more broadly, over framings of sustainability (Asara et al. 2015; Gómez-Baggethun and Naredo 2015) to discuss low-carbon transitions beyond its technical aspects (Trainer 2014; Scoones 2016). This includes addressing the structures and transformations that different paths of change could entail; considering issues of power, patterns of production-consumption and environmental rearrangements at different scales (Brand 2016; Gillard et al. 2016; Scoones 2016).

In the following section I present a review of the current "wind energy debate", discussing the narratives at stake as well as the larger environmental and political paradigms where they are inserted. I then proceed to describe the conceptual and methodological approach of the Environmental Justice Atlas, as well as the roadmap for researching the 20 conflicts presented in this article. The empirical results of the inventory are presented in two different moments. The first one (Features of large-scale projects) unpacks the social and biophysical configurations of large-scale wind farms, including aspects of ownership, installed capacity, land intensity, type 
of infrastructures and end uses of the electricity produced. This aggregated criteria helps to inform how land pressures and patterns of uneven development appear as the common byproducts of the current wind power expansion. The second part of the results (Features of conflicts) analyzes how these patterns are expressed and contested in different socio-geographical contexts around the world. Based on this roadmap, I discuss the hypothesis of an emerging environmental justice narrative in the wind energy debate. Finally, the conclusions section reflects on the how this extended debate contributes to approaching the transition in its social, political and environmental dimensions.

\section{The wind energy debate}

The "wind energy debate" is understood as the different worldviews, interests and values expressing a stance in relation to the expansion of modern wind farms, which in turn are part of wider efforts to promote low-carbon transitions. Active voices in this discussion include those of international organizations, governments, environmental groups, scientists, technocrats, social movements and local communities. Different approaches and case studies have been used to classify the plurality of story-lines and themes along this spectrum (Ellis et al. 2006; Szarka 2007; Jessup 2010). Within the complex roadmap these studies portray, a similar common pattern tends to reflect a dual tension between those who support the rapid expansion of large-scale wind farms and those who oppose to particular deployments due to concerns over landscape and wildlife conservation. In the following paragraphs, I present these tensions as being sub-themes of wider environmental debates; the first stance as embedded in the ecological modernization paradigm, and the second as part of the environmental conservation one. As I will argue, these two "factions" certainly inform and give shape to the current wind energy debate. However, emerging narratives are increasingly opening new lines of theoretical and empirical discussion. I cluster these emerging narratives under the critical environmental justice perspective.

\section{Ecological modernization}

The first faction embeds the vision of international agencies, governments, corporations and environmental groups supporting the expansion of industrial wind power as one of the most effective ways to tackle climate 
change and energy concerns (Ellis et al. 2006). Under this framing, modern wind power appears as a technological solution, but also as an opportunity to promote green business and economic growth (Jessup 2010). As such, it tends to hold that "the commercial exploitation and development of wind energy is a means (private profit making via technological innovation and government support) to an end (the public interest in security of energy supply, tackling the threat of climate change and benefiting future generations)" (Ellis et al. 2006 p.9).

This narrative derives from the ecological modernization paradigm, where the premises of environmental protection and economic growth are compatible via the development of modern technologies, improvements in efficiency, competitive markets and state interventions (Weale 1992; Mol 1996; Mol and Sonnenfeld 2000 Osland 2016). The major role that this paradigm plays in the quest for a low-carbon transition can be observed in multiple instances of the debate. In the prelude of the UN-COP 21 in Paris (2016), for example, an unprecedented mobilization of business networks stated that climate objectives are "compatible with continued economic growth and human development if all actors work together" (UN Global Compact 2016). In a similar vein, international agencies, public policies and private investors celebrate the rapid expansion of commercial renewable energy projects as a clear step to promoting green growth and achieving sustainable development goals (OECD/IEA 2014; REN21 2016).

From an ecological modernization perspective, wind turbines are seen as one of the most powerful images of nature and modernity working in harmony (Toke and Strachan 2006; Smil 2016). As such, social opposition to wind energy projects is generally described as an obstacle in the development of an energy system that is "costeffective, environmentally desirable and technically reliable" (Bosley and Bosley 1992:1). Wind is seen as an endless resource to be harvested, transformed and commodified as electricity (Hawken et al. 1999), providing new possibilities to meet increasing global energy demands (REN21 2016). Whereas this "dominant storyline" (Jessup 2010) seeks to create scientific consensus of a "technological neutrality providing unlimited economic growth" (Ellis et al 2006; Brey 2017), local groups increasingly appear as questioning the viability of such winwin scenario in terms of it social, political and environmental implications. 


\section{Environmental conservation}

Wildlife conservation and landscape protection groups lead the second faction of the debate around modern wind energy development. In contrast with the ecological modernization narratives, where the economic and scientific rationale dominates the discourse, this second faction tends to prioritize eco-centric and cultural values over affected local environments, although some utilitarian values are also present (Jessup 2010). Discourses within this faction generally acknowledge climate change as one of the greatest challenges of our times. However, localized wind farms tend to be depicted as the drivers of turning "wilderness" or "the rural" into an outdoor industrial energy production plant (Ellis et al. 2006: 6).

Regional coalitions (such as the European and North American Platforms Against Wind Energy), and wellestablished conservationist organizations (such as Birdlife International and the Royal Society for the Protection of Birds) are powerful representatives of this faction, as they question the risks of wind turbines on localized landscapes. Literature has also shown how rural and suburban communities in the Europe, Australia and the US, oppose wind farm deployments due to the visual imposition of turbines and the consequent impacts on aesthetics and cultural values (Thayer and Freeman 1987; Thayer and Hansen 1991; Pasqualetti et al. 2002, Toke and Strachan 2006, Zografos and Martinez-Alier 2009). Opposition sometimes also include claims on how the visual or cultural intrusion of turbines creates economic impacts over properties and tourism (e.g. Szarka 2007; Pasqualetti 2011).

The aggregated narratives within this faction fairly met with the traditional paradigm of environmental conservation, where much of the discourses and efforts are focused in preserving imaginaries of "wild" and "pristine" environments (Martinez-Alier 2002). Under this vision, environmental problems (pollution, degradation and depletion) are recognized as challenges for sustainability, but are generally isolated from their wider socio-economic dynamics (Martínez-Alier 2002). As such, conservation initiatives tend to establish shelters and protection measures to save certain spaces from modern human interventions, including markets and technologies. The case of wind energy clearly reflects such spectrum of stances, as conservationist 
narratives tend support the expansion of wind farms (Jessup 2010), but seek to protect sensitive rural landscapes through, for example, better siting decisions.

\section{Environmental Justice}

As wind power investments expand globally, the wind energy debate appears to go beyond the binary tension between ecological modernization and environmental conservation. One of the sources of such development derives from the environmental justice narratives and its related alternative visions of sustainability, which are both co-constructed by grassroots activism and critical social theory.

The environmental justice movement emerged since the early 1980s in the U.S. against a background of uneven distribution of environmental burdens in terms of class, gender and ethnicity (Bullard 1990; Bryant and Mohai 1992). Instances of environmental injustice and conflict have been largely analyzed in "third" and "first" world societies (Bryant and Bailey 1997; Martinez-Alier 2002; McCarthy 2005; Anguelovski and Martínez-Alier 2014), making visible the socially unequal and geographically uneven profile of the modern industrial economies (Temper et al 2015). In the most recent years, the environmental justice movement and theory has expanded to include an array of perspectives, concepts and political positions some of which will play a crucial role in debating low-carbon transitions (Bryant 2015; Perreault et al. 2015; Holifield et al 2018).

A good example of these contributions comes from the growing number of studies on the field of energy justice (Sovacool and Dworkin 2015; Bouzarovski and Simcock 2017); which are part and parcel of the "equityrecognition-participation" framework broadly proposed by Schlosberg (2013). In an effort to further understand -and challenge- the power relations embedded in the low carbon transition, critical environmental justice narratives also increase its voice in this debate. For example, when analyzing the trade-offs between "sustainable transitions" and issues of "social justice”, Newell and Mulvaney (2013) highlight that "(...) the uneven exposure to environmental benefits and harm is often not accidental and unintentional, but rather a product of a particular way of organizing production and its constitutive social relations”. From this critical lens, pure technological- 
fixes to solve the climate-energy crisis appear to reinforce (rather than revert) the uneven power relations that characterize current social structures (Swyngedouw 2010; 2011).

The analysis of environmental conflicts and claims for justice related to the expansion of renewable energies here raises a new spectrum of questions and paths of inquiry: how this transition is taking place (Dunlap 2017, Del Bene et al. this feature); by whom and for whom (Newell and Mulvaney 2013; Calvert 2016); how these new energy flows are configured by particular economic institutions and power relations (Avila-Calero 2017); and how renewable energies interlink with issues of capital accumulation, spatiality and land grabs (McCarthy 2015; Fairhead 2013; Yenneti et al 2016). The inventory of conflicts analyzed in this article seeks to provide an empirical basis to approach these set of theoretical questions. The following sections expand the wind energy debate by describing how land pressures and patterns of uneven development, derived from the expansion of large-scale wind farms, places issues of space and justice at the center of emerging conflicts.

\section{The inventory of conflicts: methods and conceptual approach}

Each case encompassing the inventory of wind energy conflicts was first filed in the Environmental Justice Atlas (Ej-Atlas). The Ej-Atlas acts as a shared platform and database to study and disseminate cases of grassroots activism emerging from the uneven distribution of environmental burdens along the commodity chains (Temper et al 2015). From a conceptual perspective, it works as an empirical tool helping to understand how changes in socio-metabolic configurations redefine the distribution of environmental benefits and burdens, socially and geographically (Scheidel et al. this feature; Pérez-Rincon et al. 2017). We define "socio-metabolic configurations" as the flow of energy and materials in the economy (Martinez-Alier 2009), as well as the institutions and power structures configuring them (Demaria and Schindler 2016; Avila-Calero 2017; Špirić 2017). As such, the study of environmental conflicts is placed as an effort to grasp the social struggles that contest those configurations, and (sometimes) revert them in favor of more socially just and environmentally sustainable arrangements (Scheidel et al. this feature). 
The Ej-Atlas database collects qualitative and quantitative data of each conflict including: description of the case, features of the project triggering conflict, perceived and potential impacts, affected population, actors mobilizing, outcomes of the conflict and sources of information. Once a case-study is completed, an internal board revises the content and sources to assure accuracy before its publication. This methodology is applied to each one of the cases and further information can be found both in the introduction of this Special Feature as well as in Temper et al. (2015). For researching the 20 wind power conflicts presented in this paper, two criteria were established in advance. 1) Covering those countries of the "Global South" that are experiencing increasing investment in large-scale wind energy projects ${ }^{1}$. 2) Including some cases in the "Global North" contributing to our understanding of new actors, claims and values in the wind energy debate. The set of 20 cases was also defined by the available information, including activist communications, newspaper articles and official documentation from companies, governments and investors ${ }^{2}$. Sources of information for each case are listed on their respective entry at the Ej-Atlas website, and direct links are provided in Table 1. Figure 1 and Table 1 present the basic information and location of these 20 conflicts.

TABLE 1. THE INVENTORY OF CONFLICTS: BASIC INFORMATION AND LINKS TO ENTRIES

\begin{tabular}{|c|c|c|c|}
\hline $\begin{array}{c}\text { Number } \\
\text { in map }\end{array}$ & Location & $\begin{array}{c}\text { Name } \\
\text { of project }\end{array}$ & $\begin{array}{c}\text { Reference } \\
\text { in text } \\
\text { (link to entry) }\end{array}$ \\
\hline 1 & Sweden, Norrbotten & Markbygden & Ejatlas, 2016f \\
\hline 2 & Mexico, Oaxaca & $\begin{array}{c}\text { Wind Corridor of the Isthmus of } \\
\text { Tehuantepec }\end{array}$ & Ejatlas, 2017a \\
\hline 3 & India, Gujarat & Ejatlas, 2017b \\
\hline 4 & Greece, Chios & Suzlon Wind Farm & Ejatlas, 2015 \\
\hline
\end{tabular}

\footnotetext{
${ }^{1}$ Note that as of now the inventory does not include any case in China, due to the inability of accessing to verifiable information.

2 Some of the cases presented in the inventory were previously researched by other contributors of the EjAtlas. In those cases, information was verified and updated to produce homogeneous coverage of information, as much as possible. (cases in Colombia, Greece, Turkey, Albania, Slovenia and Kenya-Lamu-).
} 


\begin{tabular}{|c|c|c|c|}
\hline 5 & India, Maharashtra & Suzlon Wind Farm & Ejatlas, 20171 \\
\hline 6 & Albania, Vlorë & Moncada Construzioni & Ejatlas, 2017i \\
\hline 7 & $\begin{array}{l}\text { United States, } \\
\text { Massachusetts }\end{array}$ & Cape Code & Ejatlas, 2017e \\
\hline 8 & $\begin{array}{l}\text { Western Sahara, } \\
\text { Boujourd/Tiskard }\end{array}$ & Boujourd and Tiskard & Ejatlas, $2017 \mathrm{~g}$ \\
\hline 9 & $\begin{array}{l}\text { Honduras, Fransisco } \\
\text { Morazán }\end{array}$ & Cerro de Hula & Ejatlas, 2016a \\
\hline 10 & Kenya, Marsabit & Lake Turkana & Ejatlas, 2016d \\
\hline 11 & Kenya, Lamu & Lamu Cordisons & Ejatlas, $2017 \mathrm{f}$ \\
\hline 12 & Brazil, Bahía & Alto Sertão & Ejaltas, 2016b \\
\hline 13 & $\begin{array}{l}\text { Brazil, Rio Grande do } \\
\text { Norte }\end{array}$ & Alegria & Ejatlas, 2017d \\
\hline 14 & Turkey, Izmir & Lodos Electricity & Ejatlas, $2017 \mathrm{~h}$ \\
\hline 15 & Brazil, Ceará & Baleia Complex & Ejatlas, 2017c \\
\hline 16 & Chile, Chiloé & Chiloé & Ejatlas, 2016c \\
\hline 17 & India, Andra Pradesh & Nallakonda & Ejatlas, $2017 \mathrm{~m}$ \\
\hline 18 & Colombia, La Guajira & Jepirachi & Ejatlas, 2014 \\
\hline 19 & Slovenia, Ilirska Bistrica & Elektro Primorska & Ejatlas, 2017j \\
\hline 20 & India, Maharashtra & Suzlon Wind Farm & Ejatlas, 2017k \\
\hline
\end{tabular}




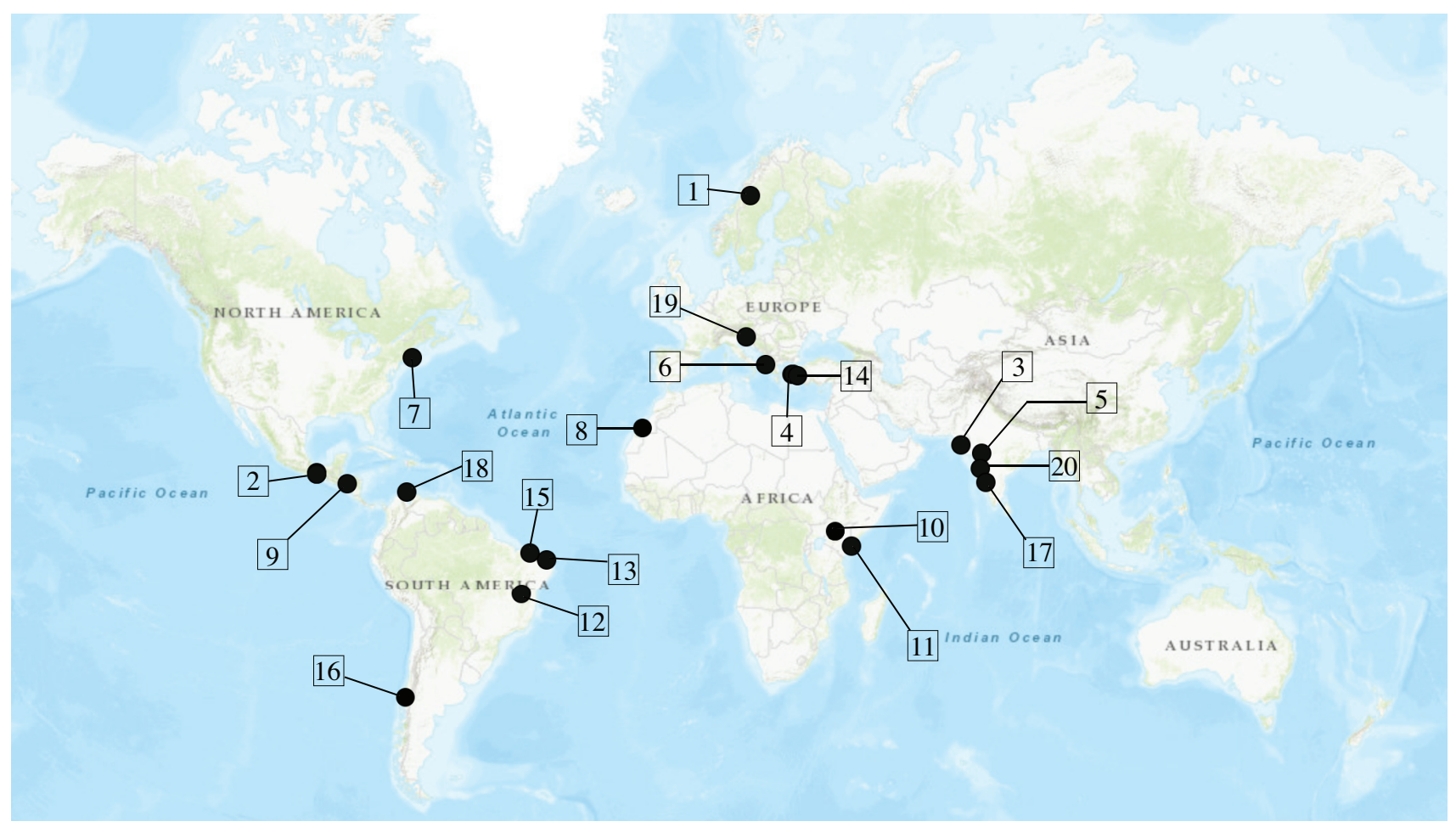

Own elaboration based on www.ejatlas.com

Taking the Ej-Atlas methodology as the starting point was crucial to go beyond the isolated case-study approach that still dominates the study of wind power opposition. When following the same analytical categories for each of the 20 cases, a systematic evidence-based inquiry was provided to explore the determinants of wind power expansion as well as the dissent voices emerging at the local scales. The Ej-Atlas also provided a well-defined analytical perspective, helping to explore the relationship between wind energy conflicts and environmental justice narratives. The display of results presented in the following sections will show that beyond the Ej-Atlas database, additional categorization and some further research was needed to answer the specific questions of this article. For example, the first section of results (features of projects) is based on the Ej-Atlas information, but enriched by literature and displayed under specific categories and estimations. The second section (features of conflicts) is also based on the derived the $20 \mathrm{Ej}$-Atlas entries, but digested and clustered into five different "socio-geographical contexts": indigenous and ethnic territories; community managed reserves; nature conservation areas; rural and peri-urban communities; and affluent suburbs. Finally, the discussion section explores how these elements (features of projects and conflicts) suggest the inclusion of environmental justice narratives in the wind energy debate. 


\section{Results}

\section{Features of projects: unpacking large-scale wind farms}

According to the Global Renewables Status Report (REN21 2016), the current expansion of renewable energies, both in general and for wind power in particular, is mainly owed to the deployment of large generators (megawatt-scale and up), owned by utilities or large investors. The 20 wind power projects analyzed in this inventory fall in this large-scale category. However, additional elements of analysis remain crucial to interrelate the scale of projects with their socio-political implications, and thus shed light on the drivers and nature of conflicts. In the following paragraphs, three additional criteria are included in order to widen our understanding of a large-scale project: 1) the associated land requirements; 2) the type of infrastructures they entail; and 3) the end users of electricity produced. Each of these criteria is conceptually described, including a brief description of such features in the inventory. This extended analysis based on the 20 cases argues how land pressures and patterns of uneven development are derived from the ongoing expansion of large-scale wind farms. Table 2 summarizes this information into a single chart.

\section{Land requirements}

Alternative energy sources require vast amounts of space to generate the energy that conventional fossil and nuclear resources can produce in focal points of extraction (Huber 2015). The high-land intensity related with renewables is a consequence of differential power densities, where the quantity of power that can be generated from a certain area depends on the resources available and harvesting technologies (Smil 2008). Power densities $\left(\mathrm{W} / \mathrm{m}^{2}\right)$ of conventional fossil and nuclear energy sources are two to three orders of magnitude greater than those of renewables ${ }^{3}$; showing that if the level of energy flows is to be maintained or increased under a lowcarbon system, area coverage of alternative energy sources will have to increase in large magnitudes (Scheidel and Sorman 2014 p. 591).

\footnotetext{
3 Power Densities: Nuclear $4000 \mathrm{w} / \mathrm{m}^{2}$, Natural Gas 200-2,000 w/m² , Coal 100-1,000 w/m²; Solar Photovoltaic 4-10 w/m²; Wind 0.5 to $1.5 \mathrm{w} / \mathrm{m}^{2}$; Biomass $0.5-0.6 \mathrm{w} / \mathrm{m}^{2}$ (Smil, 2008).
} 
In the case of wind energy, power density ranges from 0.5 to $1.5 \mathrm{~W} / \mathrm{m} 2$ (Smil 2008). However, estimating the specific power density of an individual wind farm requires considering place-specific variables and constraints (e.g. Fyrippis et al. 2010). An alternative metric to estimate land use for wind power plants is to consider two primary indices: the direct impact area (land disturbed by road development, turbine pads and electrical support equipment); and the total impact area (overall area leased or bounded for the project as a whole) (Denholm et al. 2009). Figure 2 presents approximate ranges of direct impact area and total impact area of the projects encompassing the inventory, as an illustrative example of such land use pressures.

FIGURE 2: PROXY AVERAGES OF DIRECT AND TOTAL IMPACTED AREAS

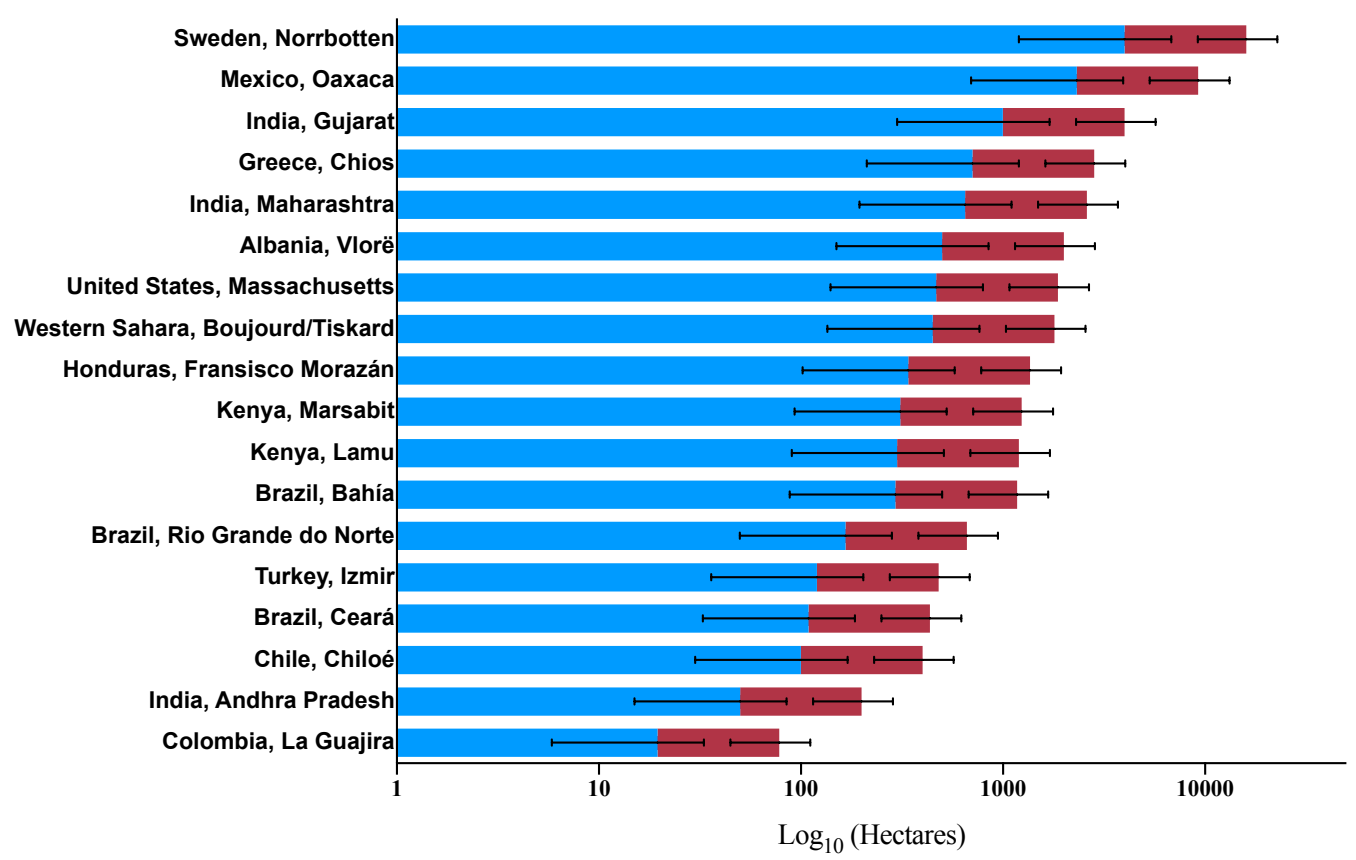

Direct impact area (ha) _ Total impact area (ha)

Own elaboration based on the installed capacities of each project and average figures from Denholm et al. 2009. Averages and their respective standard deviations are: 1) Direct impact area: $1 \pm 0.7$ hectare/MW. 2) Total impact area: $3.0 \pm 1.7$. Note that this figure is presented as a proxy and illustration of land uses, with still a wide variation in each of these indices. Also note that the cases of Slovenia (Ejatlas 2017j) and India (Ejatlas 2017k) are not included as there is no information available on the installed capacity of projects. 
Whereas these land areas are not necessarily translated into environmental impacts on the ground (especially for total impacted area estimations), such figures help to illustrate the socio-environmental rearrangements that renewable energy landscapes will entail (see for instance: Calvert 2016). In the inventory of conflicts analyzed here, this spatial dimension appears as a crucial element for understand emergent cases and discourses of contestation towards wind power. With the exception of the offshore wind farm in the US, all of the cases in the inventory (95\%) are catalogued as "land acquisition conflicts"; while some of them of them also span categories such as fishery/coastal conflicts (20\%) and deforestation (10\%). The type of impacts, claims and values mobilized in each case vary, however, depending on the specificities of the socio-geographical context at stake. Table 2 presents the general features of each of these contexts, while next section describes them in further detail.

\section{Type of infrastructures}

The second relevant criterion has to be with the type of infrastructures necessary for large-scale power production and supply. Large-scale electricity developments are usually centralized facilities providing power to distant end-users through high-voltage transmission lines (EPA $\mathrm{n} / \mathrm{d}$ ). These systems are both capital and technology intensive (Momoh et al. 2012), as well as highly dependent on concentrated property and management schemes (Kallis et al.2014). This centralized paradigm has enabled and powered modern industrial societies, as systems have relied on the highly productive, localized sources of energy (Momoh et al. 2012). Such schemes and its complex networks have been, however, deeply implicated in the reproduction of political and economic power, when differentiating spaces of production and consumption; while creating concentrated nodes of profit and control (Harrison 2013; Huber 2015).

In the low-carbon transition, a shift towards a decentralized power system appears as a concrete alternative; not just because renewables are dispersed by nature, but also because their lower productivity will require changes in production and consumption at different scales (Scheidel and Sorman 2014). However, the centralized paradigm is still dominating in the expansion of renewables, and has become the strongest model in the wind and solar sector (REN21 2016). The implications of such infrastructures in potentially reproducing energy 
poverty and injustice have been addressed as a central aspect to critically approach energy landscapes (Harrison 2013; Huber 2015). As illustrated in Table 2, cases in the inventory constitute examples of such large centralized facilities, suggesting that the uneven geographies reinforced by these schemes contribute into the emergence of local forms of contestation.

\section{End uses of electricity produced}

Closely related to the landscapes of extraction and infrastructure deployment, energy consumption patterns also reflect larger social and political structures of inequality (Huber 2015). Understanding the macro-structural processes of energy consumption requires going beyond the analysis of residential consumption behaviors to address, in turn, large organizational consumers (Huber 2013; Mitchell 2011). From this perspective, three categories of consumers are defined to analyze the cases of the inventory: 1) developed/urban regions of hosting countries; 2) demanding regions of neighboring countries; and 3) the so-called "corporate end users". This latter category refers to the growing number of bilateral agreements made between corporations, on one side, and large electricity generators, on the other (Penndorf 2015). Under this scheme, corporations invest in large-scale renewable projects in order to receive, among others, "green" electricity supply at preferential rates.

In the inventory of conflicts, the first type of sectorial end users represents the great majority of cases, as $80 \%$ of projects are deployed to supply electricity for developed/urban regions of hosting countries. In a very similar direction, two other cases illustrate examples of electricity produced to supply neighboring countries (Albania and Western Sahara). The uneven geographies created by such consumption patterns are, in many cases, explicitly addressed and contested by affected communities. Cases in India are illustrative in this regard, but also cases of Sami communities in Sweden (Ejatlas 2016f); island communities in Greece (Ejatlas 2016e); Saharahui people in Western Sahara (Ejatlas 2017g), and farmer communities in Albania (Ejatlas 2017i). Other cases in the inventory illustrate how these uneven geographies are also shaped by private-corporate consumers. Projects in the inventory representing "corporate end users" include wind farms in Western Sahara supplying electricity to the Moroccan Phosphate Company (Ejatlas 2017g), the wind corridor in Mexico supplying several multinational corporations (Ejatlas 2017a), and the project in India supplying multiple big companies (Ejatlas 
2017k). In such cases, the distributional implications play a very important role in the construction of a challenging movement against wind power production. Table 2 presents this aggregated analysis into a single chart.

TABLE 2: AGGREGATED ANALYSIS OF LARGE-SCALE PROJECTS.

(Only available in printed version)

\section{Features of conflicts: claims and actors at different contexts}

Land pressures and patterns of uneven development are perceived and contested differently, depending on the specific context where wind power projects are deployed, or planned to be installed. In the inventory of conflicts, five socio-geographical contexts have been identified as general categories of analysis (see also Table 2). This section summarizes the most salient patterns in terms of actors, claims and values mobilized towards the wind energy expansion in each one of these contexts:

\section{Indigenous and Ethnic Territories}

At least $50 \%$ of cases in the inventory unfold in contexts of indigenous and ethnic territories around the world; most of them located in the Global South but not exclusively (see: Ejatlas $2016 \mathrm{f}$ ). In these cases, land pressures deriving from the wind power expansion are directly translated into the struggles of local communities claiming territorial rights against state and corporate powers. Cases in Mexico and Kenya are illustrative in this regard, as the privatization of indigenous lands without adequate previous consultations remain the central issue of the conflict (Ejatlas 2016d; Ejatlas 2017a;b). Many other cases unfold in a similar direction: Quilombola communities in Brazil facing the wind power expansion and doubling efforts to certify their lands (Ejatlas 2016b), or Adivasis in India denouncing the private diversion of forestlands for installing large turbines (Ejatlas 20171). Records also indicate how Lenca communities in Honduras denounce the forced expropriation of ancestral territories (COPINH 2011), while private tenure in Sweden's forests facilitates the expansion of windmills in detriment of Sami herding activities. Likewise, examples in Colombia, Chile, Brazil (Ejatlas 2017c) and India (Ejatlas 2015) illustrate the disruption of ancestral territories, while the installation of industrial 
turbines remains potentially problematic for different land uses in Lamu, Kenya (Ejatlas 2017f). The case of Western Sahara appears as well as an illustrative example, as Saharaui people claim that the installation of three projects reinforces the illegal Moroccan occupation of their territory.

This large set of examples illustrate how land use and tenure changes occurring with the wind power expansion create new forms of environmental change, unevenly affecting the access to resources and signifiers of territories. In this regard, claims of local communities strongly focus on the challenges to maintain both their livelihoods and cultural identities; including communal institutions, self-determination, and cultural autonomy. Public statements about communities not being against renewable energies but rather the ways in which projects are deployed are also recurrent in these conflicts. In Mexico, for example, a woman indigenous leader insists that Zapotecos and Huaves are not against wind power, but are opposed to land grabbing and its impact on local communities (Chávez 2014). In Brazil, communities state that they are not against wind energy but are against the violation of their territorial, political and environmental rights (Ejatlas 2017c). Sami representatives refer to the project as "the latest chapter in a longstanding struggle between Sámi reindeer herders and industrial interests," and then declare "we're not against wind power, but we are opposed to big wind farms since (...) local Sámi herders will lose about a quarter of their winter grazing land" (Sullivan 2010). The critical views these stances reflect, seem to place industrial wind power as external forces enhancing historical patterns of inequality and injustice.

\section{Community Managed Reserves}

Two cases in the inventory illustrate the deployment of large-scale projects inside community-managed reserves. In such instances, land pressures and patterns of uneven development have been manifested in challenges to maintain environmental restoration efforts sustaining local livelihoods. The first case unfolds in the area of the Kalpavalli Community Forest, located in the state of Andra Pradesh, India. Kalpavalli is widely known as a grassroots restoration initiative that transformed a barren territory through forest management, watershed development and the creation of sustainable forest livelihoods. Despite its successful outcomes, the area of Kalpavalli formally remained as "wasteland", allowing a private company to purchase part of its land to 
develop a project inside the forest. As with many other cases in India, the political construction of the concept of "wasteland" has facilitated land acquisitions that reshape agrarian livelihoods to promote the industrial expansion in the country (see for instance: Baka 2013). Additionally, the expansion of wind energy in India does not follow any environmental norms, and land deforestation required for wind power deployments is somehow tolerated (CSE 2013). The deployment of a project inside the Kalpavalli forest has therefore triggered legal claims against the degradation of productive lands and water sources that previously sustained the local project.

A similar situation occurred in the reserve of Ponta do Tubarão, located in the state of Rio Grande do Norte, Brazil. Ponta do Tubarão was established in 2003 after a decade of activist and local communities' struggles against attempts to develop infrastructure and extractive projects in the area. The recent installation of different windfarms inside the reserve created tensions between local communities, reserve administrators and federal government agencies. While the formers have claimed that the project would have a huge impact on local livelihoods and economic activities, the Technical Director of the reserve has argued that wind farms are in accordance with the rules governing the conservation unit as it "is considered clean" (Araújo 2012).

Both of these cases illustrate that land purchases or leasing contracts do not necessarily displace local communities, but that changes in the rights to use and manage parts of the territory do affect existing grassroots initiatives. Interestingly, the legal and institutional mechanisms encouraging the development of windfarms inside these community managed reserves, are tightly related with national aims of modern industrialization throughout sustainable development initiatives. Paradoxically, patterns of uneven development are reinforced as such national efforts imply the partial clearance of alternative local models for sustainable management and community reproduction.

\section{Rural and peri-urban communities}

Two conflicts in southeastern Europe constitute cases of rural and peri-urban communities mobilizing against the impacts of large-scale wind energy projects. In such cases, impacts at local scales appear to be addressed by 
a combination of "landscape conservation" narratives and critical perspectives over the implications of the industrial and uneven expansion of wind power. The first case unfolds in the island of Chios, Greece, where seven wind farms led to the organization of a local movement: Chios' Citizens against Windmills. The movement denounced the potential impact of projects over natural protected areas and archeological sites. However, these well-known concerns were complemented by a strong position against the uneven character of the project: electricity produced would not promote a progressive shift in the electricity system of the island (which currently depends on a hydropower plant), but instead would supply continental Greece through expensive submarine cables. Chios' Citizens then established a coordination network with the rest of the northern Aegean Islands to discuss the expansion of industrial wind energy projects and the consequent concerns deriving from uncontrolled economic growth. The network proposed alternative development projects for the islands considering their autonomous character and its socio-natural limits. Alternatives included plans for renewable energy projects, with medium-small voltage supply for local consumption (see: www.eyploia.gr).

The combination of conservationist values and critical narratives were also expressed within communities of the Karaburun region, Turkey. In this case, local residents initiated a court case against a project to be located on public lands forested with olive trees. Land pressures and patterns of uneven development appeared to be addressed both in terms of the "aesthetic impacts over the local landscape" as well as on the "threats to grazing lands and the local development project". This aggregated narrative was also illustrative in a public statement where opponents claimed: "this about our nature, all living beings, the health of the people and our future. We will not allow them to turn our beautiful peninsula into an industrial energy zone in the name of 'green energy' in this illegal way" (EPAW 2015).

\section{Nature Conservation Areas}

Four cases in the inventory represent examples of wind energy projects installed (or planned to be installed) inside nature conservation areas. In these cases, land pressures and patterns of uneven development are addressed in rather distinctive ways. Some of these cases illustrate the traditional "conservation" perspective, where eco-centric values over "landscapes" are mobilized by local authorities and environmental organizations. In Slovenia, for example, an NGO coalition was established to protect what is considered "the natural patrimony 
of the country" (volovjareber.si). Similarly, the Ekolevizja Network in Albania opposed a project that was to be installed in the Karaburuni Peninsula, considered "one of the most pristine sites of the Mediterranean". In this latter case, however, conservationist values were also accompanied by critical narratives challenging the fact that the electricity produced would supply northern Italy through a $145-\mathrm{km}$ submarine power cable. Opposition in the Albanian case aligned then with wider campaigns against the expansion of foreign investments in the country. Patterns of uneven development where therefore addressed as part of a larger movement against the development of large-scale energy facilities for export purposes (see: Bankwatch Network 2010).

Cases unfolding outside Europe also illustrate the combination of different actors, values and claims when nature conservation areas are potentially affected by wind energy projects. In the Western Ghats of Maharastra, India, the installation of thousands of turbines around the Koyna Sanctuary triggered different local reactions. On one side, land pressures and patterns of uneven development were addressed by local residents who denounced irregular land purchases and encroachments, affecting grazing activities sustaining communities in the surroundings of the Sanctuary. On the other side, conservationist organizations raised public concerns on deforestation and biodiversity loss caused by the installation of wind turbines inside the Sanctuary. Seemingly, this case gained major attention when the latter faction mobilized public denounces and leaded the narrative against the project. In a similar way, a project proposed in Lamu, Kenya, triggered opposition from Africa's oldest environmental society and member of the Royal Society for the Protection of Birds. Claims of Nature Kenya included the need to carry out detailed biodiversity surveys, to adopt avian-safe wind farm design, as well as to implement a monitor biodiversity framework. In this case, land pressures over local communities appeared in a seemingly secondary place, even when territorial controversies also constituted a potential impact of the project.

\section{Affluent suburbs in coastal areas}

Cases of affluent communities opposing the installation of wind energy projects have already been covered in the existing literature (e.g. Szarka 2007; Pasqualetti 2011). In the inventory of conflicts presented here, only the Cape Wind Project is an example of this type of context and opposition, although it evolves in a rather sui 
generis way. This is the first offshore wind farm proposed in the US, involving the installation of 130 turbines along the coast of the Nantucket Sound, Massachusetts. As such, land pressures appear to be closer to a spatial pressure over the coastal area, while patterns of uneven development are not explicitly addressed as a local problem.

Widely known as an affluent suburb, the Nantucket Sound community has developed a long-standing opposition throughout the defense of conservationist and utilitarian values over the area. The narrative has focused on claiming that such an "industrial installation" would create negative impacts on a landscape sustaining business, tourism, leisure and spiritual aesthetics. Although Massachusetts' prosperous communities have mobilized since 2002, it was until 2010 that the conflict gained major attention as the Mashpee Wampanoag Tribe raised their voice requesting the Sound be declared eligible for listing on the National Register of Historic Places. Allusions to landscape values were therefore made by different social groups, although these groups likely had different interests. This unexpected coalition, however, was institutionalized through the creation of The Alliance to Protect Nantucket Sound, an organization providing alternative developments for Massachusetts communities. Chambers of commerce, fishermen, native American tribes, ferry operators, airport commissioners, business trade groups, municipalities and homeowners aligned to develop a cohesive discourse stating that the indiscriminate expansion of renewable projects was not contributing to reduce oil dependence. As such, they proposed new policies in the transport sector and proceeded with renewable sources of energy only where deemed appropriate, responsible and efficient, including both large and small-scale technologies (saveoursound.org).

\section{Discussion}

\section{Widening the wind energy debate}

The global expansion of wind energy and the increasing number of conflicts emerging against large-scale wind farms suggests a changing path in the scope and content of the wind energy debate. This scenario has both a 
conceptual and empirical basis, as cross-disciplinary literature increasingly discusses renewable landscapes, while new conflicts point out emergent narratives of contestation and alternatives. In this growing debate, it has become clear that questions are not about wind power itself, but instead about the ways wind power is being portrayed, arranged and deployed around the world. In particular, these new insights contribute to place the wind energy expansion as embedded in the politics of truth, rule and accumulation (Scoones 2016) of the lowcarbon transition. Grasping this growing conversation requires a relational analysis, paying attention to both the configuration of wind farms, as well as to the specific contexts and power relations where these technologies are deployed. This paper proposed an explorative effort to approach such emerging issues using 20 cases of wind power projects and conflicts emerging in different locations across the globe.

When analyzing the configuration of modern wind farms, a "socio-metabolic" approach was proposed to understand how wind power production is taking place; how such energy flows within societies; and how these production-flows are being shaped by specific power structures. As observed, the intrinsic nature of wind and renewables -more dispersed and less productive than conventional sources- combined with the aims of maintaining or increasing current patterns of energy consumption, is deriving into inconvenient socioenvironmental arrangements. On one side, this is expressed in great extensions of land use, involving major new productions of space in the rural areas of the world (McCarthy 2015). On the other, such arrangements associate with the reproduction of centralized schemes in terms of ownership, control and distribution of electricity; with similar distributional effects as those created by conventional energy systems (Harrison 2013; Huber 2015). I refer to these aspects as the "land pressures" and "patterns of uneven development" in the global expansion of wind power.

Contemporary configurations of wind power are seen as an essential part of the ecological modernization paradigm, where the low-carbon transition appears as an effort to "green" energy systems, rather than transforming the societal structures behind them (Fauset 2010; Bradley and Hedrén 2014). These global trends are expressed in the Global North and South alike, as investment flows into the rural spaces, unevenly integrating them into the circuits of capital accumulation (Rignall and Atia 2016). The idea of a "global rural" in the wind power expansion does not dilutes, however, the specific context and power relations where projects 
are sited (see also: Rignall and Atia 2016). A contextual approach to wind power conflicts then appears as the second part of the analysis, helping to understand how land pressures and patterns of uneven development are expressed and contested in different locations of the world.

The five socio-geographical contexts analyzed in the inventory reflect a wider roadmap of actors, values and political implications of the "wind energy debate" (Ellis et al. 2006; Szarka 2007; Jessup 2010). In this scenario, a spectrum of environmental justice narratives appears as variable forms of collective action on socioenvironmental concerns related with the current wind power expansion (see: Walker 2009). Such narratives appear in dynamic dialogue with the specific power structures and land uses of each context at stake, reflecting how uneven patterns of wind power are contested. As previously observed, conservation narratives are also present in this scenario as forms of "wildlife" and "landscape" protection. This has been particularly clear in contexts where land pressure is perceived as a threat to spatial shelters protecting "nature" from the industrial world. However, an interesting source of "hybrid coalitions" (Jessup 2010) emerges when critical environmental justice perspectives are combined with the "green credentials" of conservation initiatives, contesting the patterns of uneven development derived from the expansion of large-scale wind farms.

In the inventory, the spectrum of environmental justice narratives opens in contexts of indigenous and ethnically discriminated territories. Land pressures are crucial in these cases, as acquisitions for wind power development disproportionally affect populations with less power and fewer formal land rights (McCarthy 2015). Longstanding resistance to protect these territories from state and corporate powers take here a new "environmental dimension" (Robbins 2004); insofar communities experience the expansion of wind energy as forces enhancing historical patterns of injustice. In contrast with the concept of "land" (subjected to fragmentation and commercial exchange), the notion of "territory" appears as the set of complex relationships between the economic, cultural and ecological spheres of placed-based social groups (Sawyer 2004; Rocheleau 2015a,b). Whereas indigenous and ethnic groups analyzed here openly express that they are not against wind energy per se, they do stand against projects that reorganize local territories in ways that reinforce political, economic and cultural inequalities (see also: Fairhead et al. 2012). Territorial advocacy therefore emerges as a matter of 
defending the material basis of community existence (Martinez-Alier 2002), but also as a question of holding their political autonomy to reproduce alternative socio-natures (Escobar 2008).

Similar situations unfold within community managed reserves, as environmental justice narratives appear along the challenges to maintain restoration efforts sustaining livelihood security. When national aims to promote low-carbon industrial transitions encounter grassroots initiatives for livelihood sustainability, affected communities openly question the technical standards of appropriation of the territory and its resources (Acselrad 2010: 103). What is at stake, therefore, is the question of who owns the power to impose particular understandings of sustainability and who benefits from it at different geographical scales. Environmental justice narratives also appear in the context of rural and peri-urban communities in the south of Europe, although in differing ways. In contrast with the territorial content of indigenous and ethnic struggles, these instances illustrate a combination of "landscape conservation" narratives and critical perspectives the expansion of industrial wind power. As observed, land pressures are manifested as concerns over natural areas, archeological sites, and aesthetical landscapes; but also as challenges to maintain the common productive and political projects of local communities. In the North Aegean Islands, there is an explicit stand to defend a small-scale sustainable project based on the natural limits of the area, while the Karaburun community defends reforestation initiatives as part of local development plans. When explicitly challenging the uneven patterns of industrial renewable energies, these cases illustrate a clear denunciation against uncontrolled economic growth and the consequent harm of communities' futures. Analogous to what happens with the spatial requirements of large-scale projects, the distributional dimension related with the end uses of electricity appears as a recurrent issue in the analyzed conflicts, both in northern and southern contexts. As such, the inventory suggests that uneven relations in energy matters are not just expressed at a global scale (e.g. Hornborg 2014) but also at lower regional dynamics (e.g. between the urban and the rural, as well as between high and low-income regions).

Some cases of nature conservation areas affected by the expansion of large-scale wind farms also incorporate environmental justice dimensions to their "eco-centric" claims. Whereas the case in Slovenia represents an example of clear "wildlife conservation" narratives; in the case of Albania these concerns are combined with environmental justice perspectives. As previously observed, the Ekolevizja Network is not just concerned with 
the protection of "the last unspoiled places of the Mediterranean", but also with the distributional implications of a project destined to supply bulk power to its powerful neighbor country. Within this category, examples unfolding in India and Kenya also illustrate that potential alliances between conservation and environmental justice narratives gives further strength to promote changes in the ways under which wind power is being deployed. Whereas conservationist narratives provide the "green credentials" to question the deployment of industrial installations, environmental justice stances mobilized by surrounding communities render the critical stream to challenge the wider social implications of such facilities.

Alliances between different narratives are also present in the context of the coastal area of Massachusetts. Due to the specificities of the context in this case, land pressures and patterns of uneven development to not appear to be clearly addressed by affected populations. However, a "landscape conservation" alliance was made between radically different groups. It is worth noting how this case gained major attention when tribal communities placed their cultural claims over state courts. An interesting "productive outcome" (Merlinski 2005) emerged afterwards, as the explicit alliance between different groups enabled further discussions about the ways under which the low-carbon transition should take place in the region.

\section{Conflicts as sources for alternatives}

The perception of what is a successful outcome in wind energy conflicts might be rather different to perceptions in other instances of environmental injustice. Whereas in oil, gas or nuclear energy-related conflicts, the cancellation of projects is normally framed as the expected outcome for attaining environmental justice, what seems to be more relevant in the case of wind energy is the institutional, technological or political alternatives that these conflicts might bring about. From this perspective, cases of local opposition are not interpreted as regressive forces blocking the possibility of an energy transition, but instead are understood as political instances that enable a wider discussion to occur on the ways such transition should take place.

From a broad perspective, the very existence of local mobilizations helps to shed light on the emergent forms of environmental change and injustices that could be prevented. Some other cases also illustrate how local opposition has enabled a progressive institutional reform in the wind power sector, either by promoting the 
implementation of previous environmental impact assessments (for the case of India see: CSE 2013) or by reclaiming formal consultation processes for indigenous and other discriminated groups (for the case of Colombia see: Rojas 2012). These are examples of conflicts with "productive" outcomes (Merlinsky 2015), as local opposition promotes new public debates on the way institutions should regulate the expansion of wind energy facilities. The spectrum of these narratives covers issues of equity, recognition and participation widely discussed within environmental justice scholarship (Schlosberg 2013).

The spectrum of environmental justice narratives also illustrates the presence of more challenging perspectives, where the technological fixes and its possible negotiated outcomes are seen as insufficient sources to build alternative energy futures. The defense of "energy sovereignty" (Mexico), "territorial autonomy” (Mexico and Western Sahara), "energy decentralization" and "limits to economic growth" (Greece), are strong examples in this regard. Equivalent importance is placed on the local initiatives deriving from such perspectives: the defense of maintaining previous communities' projects as a source of local sustainability, the promotion of wind power cooperatives in Mexico (Ejatlas 2017b), as well as the proposal of deploying medium-scale windfarms for electricity supply in Greece.

In a similar direction, the increasing number of instances where "hybrid coalitions" take place (Jessup 2010), appear as a potential source for re-configuring the wind power expansion. These alliances could be built not just between environmental justice and conservationist narratives (e.g. Foyer and Dumoulin 2015), but also between these movements and emerging paradigms for social transformation (Martínez-Alier 2012; Kothari et al. 2014; Temper et al, this issue). As energy systems need to be taken beyond a matter of technological change or resource switch, the intervention of plural socio-political visions is placed as a crucial element for transformative action. Rather than a technological transition, transformation paradigms appear to shed light on the need to cover the social, cultural and political dynamics of alternative energy futures (Brand, 2016; Gillard et al., 2016; Scoones, 2016). The pathways of conflicts and potential alliances that could be enabled in the following years, will play a crucial role in this changing and rich debate. 


\section{Conclusions}

Dominant narratives supporting a pure technological fix towards large-scale renewables are increasingly questioned by multiple forms of social dispute and agency. The study of environmental conflicts related with the expansion of wind power appears as an illustrative example of these processes. When approaching the current expansion of wind power from a relational perspective, new insights shed light over the socioenvironmental implications of such deployments at the local scales. As outlined in this article, the configuration large scale wind farms increasingly derive into land pressures and patterns of uneven development throughout the global rural. The growing presence of environmental justice narratives at different contexts of the world, contribute to unveil and contest these inconvenient arrangements in multiple ways.

Rather than framing opposing voices as selfish expressions blocking the cultural change needed to move towards renewables, the political value of these movements resides in their capacity to expand the possibilities of imagining alternative energy futures. Even when modern technologies deliver partial solutions for the climate/energy crisis, social and spatial issues are expected to arise if they are not accompanied by changes to demand, all of which requires economic and social transformations (Fauset 2010; Trainer 2014; Scheidel and Sorman 2012). Plural voices emerging at the local scale bring novel directions for imagining such transformations, including issues of technological ownership and scale, as well as different infrastructures and the final uses of electricity. In this regard, local mobilizations and novel alliances contribute to discuss energy transitions as a societal matter, rather than a technical and managerial issue.

\section{Acknowledgements}

The author is financially supported by CONACYT-Postgraduate Research Grant. This article was developed within the ENVJUSTICE Project (European Research Council/No 695446). Thanks to the editors of the Special Feature: “The EJAtlas: Ecological Distribution Conflicts as Forces for Sustainability”. Thanks to Joan MartínezAlier, Leah Temper, Alevgul Sorman, Gonzalo Gamboa and Lewis King for supporting the writing process. Special thanks to the two anonymous reviewers who engaged with the manuscript providing valuable insights. Any error remains on the author. 
Compliance with ethical standards

Conflict of Interest: the author declares that there is no conflict of interest

\section{References}

Acselrad H (2010) The "environmentalization" of social struggles, the environmental justice movement in Brazil. Estudos Avançados 24(68): 103-119.

Agterbosch S, Glasbergen P, Vermeulen WJV (2007) Social barriers in wind power implementation in The Netherlands. Renewable and Sustainable Energy Reviews 11 (6): 1025-55.

Anguelovski I, Martinez-Alier J (2014) The "environmentalism of the poor" revisited: Territory and place in disconnected global struggles. Ecological Economics 102: 167-76.

Araújo R (2012) Moradores regaem a usinas eólicas. Tribuna do Norte. Published: 08/01/2012 Last access: 01/03/17. Available at:

http://www.tribunadonorte.com.br/noticia/moradores-reagem-a-usinas-eolicas/208373

Asara V, Otero I, Demaria F, Corbera E (2015) Socially sustainable degrowth as a social-ecological transformation: Repoliticizing sustainability. Sustainability Science 10 (3): 375-384

Avila S (2017) Contesting energy transitions: wind power and conflicts in the Isthmus of Tehuantepec. Journal of Political Ecology 24:993-1012

Baka J (2013) The Political Construction of Wasteland: Governmentality, Land Acquisition and Social Inequality in South India. Development and Change (44) 2: 409-428 
Bankwatch Network (2010) Over the edge: Enel's plans to export its pollution to Porto Romano, Albania. Last access: 03/29/17. Available at: http://bankwatch.org/documents/PortoRomanoOverTheEdge.pdf

Bell D, Gray T, Haggett C (2005) The "social gap" in wind farm siting decisions: explanations and policy responses. Environmental Politics 14: 460-477.

Birdlife International (2017) Migratory Soaring Birds Project, Last access: 01/03/17. Available at: http://migratorysoaringbirds.undp.birdlife.org/en/

Bosley P, Bosley K (1992) Risks and Benefits of Wind Generated Electricity. Energy Sources 14:1-9.

Bouzarovski S, Simcock N (2017) Spatializing energy justice. Energy Policy. In press.

Bradley K, Hedrén J (2014) Utopian Thought in the Making of Green Futures. In: Bradley K, Hedrén J (eds), Green Utopianism: Perspectives, Politics and Micro-Practices, Routledge, New York, Oxon, pp 1-20

Brand U (2016) "Transformation" as a New Critical Orthodoxy. The Strategic Use of the Term “Transformation” Does Not Prevent Multiple Crises. GAIA 25(1): 23-27

Brey P (2017) Sustainable Technologies for Sustainable Lifestyles. In: Kaplan M.D, Philosophy, technology and the environment. MIT Press Scholarship Online.

Brown KB (2011) Wind power in northeastern Brazil: Local burdens, regional benefits and growing opposition. Climate and Development 3:344-360.

Bryant RL, Bailey S (1997) Third World Political Ecology. Routledge, London 
Bryant B, Mohai P (1992) Race and the incidence of environmental hazards: A time for discourse. Westview Press, U.S.

Bryant RL (ed.) (2015) The International Handbook of Political Ecology. Edward Elgar, UK-USA.

Bullard R (1990) Dumping in Dixie: Race, Class, and Environmental Quality. Westview Press.

Calvert K (2016) From 'energy geography' to 'energy geographies': Perspectives on a fertile academic borderland. Progress in Human Geography 40(1): 105-12

Centre for Science and the Environment-CSE (2013) EIA Guidelines Wind Power Sector, New Delhi.

Chávez A (2014) Resistencia a las eólicas en Oaxaca. Donde el viento vale oro. Entrevista con Bettina Cruz Velázquez. En: La Jornada, Ojarasca, Published:2014/10/11. Last access: 03/29/17. Available at: http://www.jornada.unam.mx/2014/10/11/oja- viento.html

Consejo Cívico de Organizaciones Populares e Indígenas de Honduras-COPINH (2011) Proyecto Eólico del Cerro de Hula destroza nuestras tierras y afecta nuestras vidas, agua y comunidades. Published: 03/11/2011. Last access: 03/29/17. Available at: https://copinh.org/article/proyecto-eolico-del-cerro-de-hula-destrozanuestra/

Del Bene D, Scheidel A, Temper L (this feature) More dams, more violence? A global analysis of resistance, repression and violence around dams. Sustainability Science, this feature.

Demaria F, Schindler S (2016) Contesting Urban Metabolism: Struggles Over Waste-to-Energy in Delhi, India. Antipode 48:293-313 
Denholm P, Hand M, Jackson M, Ong S (2009) Land-Use Requirements of Modern Wind Power Plants in the United States. National Renewable Energy Laboratory, USA.

Dunlap A (2017) Wind Energy: Toward a "Sustainable Violence" in Oaxaca. NACLA Report on the Americas 49(4):483-488

Ejatlas (2014) Parque eólico Jepirachi, Colombia, in: Atlas of Environmental Justice, Last access: 03/29/17. https://ejatlas.org/conflict/parque-eolico-jepirachi-colombia

Ejatlas (2015) Suzlon Energy windfarms in Kutch District, India, in: in: Atlas of Environmental Justice, Last access: 03/29/17. http://ejatlas.org/conflict/suzlon-energy-in-kutch-district

Ejatlas (2016a) Proyecto eólico del Cerro de Hula, Honduras, in: Atlas of Environmental Justice, Last access: 03/29/17. https://ejatlas.org/conflict/proyecto-eolico-del-cerro-de-hula-honduras

Ejatlas (2016b) Quilombola communities affected by wind power projects in Caetité region, Brazil, in: Atlas of Environmental Justice, Last access: 03/29/17. https:/ejatlas.org/conflict/quilombola-communities-affected-by$\underline{\text { wind-power-projects-in-caetite-region-brazil }}$

Ejatlas (2016c) Chiloé wind power project in Mapuche territory, Chile. in: Atlas of Environmental Justice, Last access: 03/29/17. http://ejatlas.org/conflict/chiloe-wind-power-project-in-mapuche-territory

Ejatlas (2016d) Lake Turkana Project in Indigenous Territories, Kenya, in: Atlas of Environmental Justice, Last access: 03/29/17. http://ejatlas.org/conflict/lake-turkana-project-in-indigenous-territories 
Ejatlas (2016e) Movement against industrial Renewable Energy Resources (RES) in Chios, Greece, in: Atlas of Environmental Justice, Last access: 03/29/17. https://ejatlas.org/conflict/movement-against-industrialrenewable-energy-resources-res-in-chios

Ejatlas (2016f) Large-scale Wind Farm in Sami reindeer land, Sweden, in: Atlas of Environmental Justice, Last access: 03/29/17. http://ejatlas.org/conflict/large-scale-wind-farm-in-sami-reindeer-pastures

Ejatlas (2017a) Mareña Renovables in San Dionisio del Mar, Oaxaca, Mexico, in: Atlas of Environmental Justice, Last access: 03/29/17. https://ejatlas.org/conflict/marena-renovables-in-san-dionisio-del-mar-oaxaca

Ejatlas (2017b) Corporate Wind Farms in Ixtepec vs community's inititiative, Oaxaca, Mexico, in: Atlas of Environmental Justice, Last access: 03/29/17- http://ejatlas.org/conflict/communal-members-of-ixtepeccontending-to-develop-a-wind-farm-cooperative

Ejatlas (2017c) Baleia Wind Power Complex in Ceará, Brazil, in: Atlas of Environmental Justice, Last access: 03/29/17. https://ejatlas.org/conflict/baleia-wind-power-complex-in-ceara-brasil

Ejatlas (2017d) Wind Farms in the Sustainable Development Reserve of Ponta do Tubarão, Brazil, in: Atlas of Environmental Justice, Last access: 03/29/17. https://ejatlas.org/conflict/wind-farms-in-the-sustainabledevelopment-reserve-of-ponta-do-tubarao-brasil

Ejatlas (2017e) Tribals and wealthy residents against Cape Wind Farm, Massachusetts, USA, in: Atlas of Environmental Justice, Last access: 03/29/17. http://ejatlas.org/conflict/tribal-opposition-against-cape-wind$\underline{\text { farm }}$

Ejatlas (2017f) Lamu Cordisons Wind Power Project, Kenya, in: Atlas of Environmental Justice, Last access: 03/29/17. https://ejatlas.org/conflict/lamu-cordisons-wind-power-project-kenya 
Ejatlas (2017g) Wind Power Plants in occupied territories of Western Sahara, in: Atlas of Environmental Justice, Last access: 03/29/17. http://ejatlas.org/conflict/wind-power-plants-in-occupied-territories-of-western-sahara

Ejatlas (2017h) Unlawful removal of olive trees and wind energy project in Karaburun, Turkey. in: Atlas of Environmental Justice, Last access: 03/29/17. https://ejatlas.org/conflict/unlawful-removal-of-olive-trees-andwind-energy-project-in-karaburun-turkey

Ejatlas (2017i) Wind Farm Installation in the Protected Area of Karaburuni Peninsula, Albania, in: Atlas of Environmental Justice, Last access: 03/29/17. https://ejatlas.org/conflict/wind-farm-installation-in-theprotected-area-of-karaburuni-peninsula-albania

Ejatlas (2017j) Wind farm at Volovja reber, Slovenia, in: Atlas of Environmental Justice, Last access: 03/29/17. https://ejatlas.org/conflict/wind-farm-at-volovja-reber-slovenia

Ellis G, Barry J, Robinson C (2006) Renewable energy and discourses of objection: towards deliberative policy making. Report of ESRC research project by Queen's University, Belfast. Available at: https://www.qub.ac.uk/research-centres/REDOWelcome/filestore/Filetoupload,40561,en.pdf

Escobar A (2008) Territories of Difference: Place, Movements, Life, Redes. Duke University Press, Durham, NC.

Eyploia (n/d) Last access: 03/29/17. Available at: http://www.eyploia.gr/index.$p h p ?$ option=com content \&view=article \&id=76\&Itemid=203

Fairhead J, Leach M, Scoones I (2012) Green Grabbing: a new appropriation of nature? The Journal of Peasant Studies 39(2): 237-261 
Fauset C (2010) The Techno-Fix Approach to Climate Change and the Energy Crisis, Issues and Alternatives. In: Abramsky K, Sparking a worldwide energy revolution: social struggles in the transition to a post-petrol world. AK Press, USA, pp 300-310

Foyer J, Dumoulin KD (2015) The environmentalism of NGOs versus environmentalism of the poor? Mexico's social-environmental coalitions. In: Almeida P, Cordero UA (Eds.), Handbook of Social Movements across Latin America. Springer, New York-London, pp 223-235.

Ioannis Fyrippis I, Axaopoulos PJ, Panayiotou G (2010) Wind energy potential assessment in Naxos Island, Greece. Applied Energy 87: 577-586

Gillard R, Gouldson A, Paavola J, Van Alstine J. (2016) Transformational responses to climate change: beyond a systems perspective of social change in mitigation and adaptation. WIREs Climate Change 7:251-265.

Gómez-Baggethun E, Naredo JM (2015) In search of lost time: The rise and fall of limits to growth in international sustainability policy. Sustainability Science 10: 385-395.

Harrison C (2013) The historical-geographical construction of power: electricity in Eastern North Carolina. Local Environment 18(4): 469-486.

Hawken P, Lovins A, Lovins H (1999) Natural Capitalism: Creating the Next Industrial Revolution. Little, Brown \& Company, Boston.

Holifield R, Chakraborty J, Walker G (2018) The Routledge Handbook of Environmental Justice. Routledge 
Hornborg A (2014) Why Solar Panels Don't Grow on Trees: Technological Utopianism and the Uneasy Relation between Marxism and Ecological Economics. In: Bradley $\mathrm{K}$ and Hedrén J (eds) Green Utopianism: Perspectives, Politics and Micro-Practices. Routledge, pp 76 - 97

Huber M (2015) Theorizing Energy Geographies. Geography Compass (2015): 1-12

Jessup B (2010) Plural and hybrid environmental values: a discourse analysis of the wind energy conflict in Australia and the United Kingdom. Environmental Politics 19: 21-44

Kallis G, Demaria F, Dalisa G (2014) Introduction. In: D'alisa G, Demaria F, Kallis G. Degrowth: a vocabulary for a new era. Routledge, Oxxon, pp 28-45

Kothari A, Demaria F, Acosta A (2014) Buen Vivir, Degrowth and Ecological Swaraj: Alternatives to sustainable development and the Green Economy. Development 57(3): 362-375.

Martínez-Alier J (2002) The environmentalism of the poor: a study of ecological conflicts and valuation. Edward Elgar, Cheltenham.

Martinez-Alier J (2009) Social Metabolism, Ecological Distribution Conflicts, and Languages of Valuation. Capitalism Nature Socialism 20:58-87.

Martínez-Alier J (2012) Environmental Justice and Economic Degrowth: An Alliance between Two Movements. Capitalism Nature Socialism 23(1): 51-73

McCarthy J (2015) A socioecological fix to capitalist crisis and climate change? The possibilities and limits of renewable energy. Environment and Planning A 47: 2485 - 2502. 
Merlinsky MG (2015) Los conflictos ambientales y el debate público sobre el desarrollo en Argentina. Ciencia e Investigación 65 (3): 5-17

Mitchell T (2011) Carbon democracy: political power in the age of oil. Verso, London

Mol A (1996) Ecological modernisation and institutional reflexivity: environmental reform in the late modern age. Environmental Politics 5: 302-323.

Mol A, Sonnenfeld D (2000) Ecological modernisation around the world. Environmental Politics 9(1).

Newell P, Mulvaney D (2013) The political economy of the 'just transition'. The Geographical Journal 179:132-140.

Osland O (2016) Ecological Modernisation Revisited In Norway. World Political Science 12: 347-371.

Pasqualetti MJ (2011) Opposing Wind Energy Landscapes: A Search for Common Cause. Annals of the Association of American Geographers 101: 907-917.

Pasqualetti MJ, Gipe P, Righter RW (2002) A landscape of power. In: Pasqualetti MJ, Gipe P, Righter RW (eds) Wind Power in View: Energy Landscapes in a Crowded World, Academic Press, pp 3-16

Penndorf SB (2015) The Renewable Energy Market is Evolving. Here's How. Rocky Mountain Institute. Published: 11/02/2015. Last consulted: 06/01/2017.

Pérez-Rincón M, Vargas-Morales J, Crespo-Marín J (2017) Trends in social metabolism and environmental conflicts in four Andean countries from 1970 to 2013. Sustainability Science, this feature: 1-14. 
Perreault T, Bridge G, McCarthy J (2015) The Routledge Handbook of Political Ecology, Routledge, OxonNY.

Petrova AM (2013) NIMBYism revisited: public acceptance of wind energy in the United States. Wiley Interdisciplinary Reviews: Climate Change 4:575-601.

Rignall K, Atia L (2016) The global rural: Relational geographies of poverty and uneven development. Geography Compass (11)

Robbins P (2004) Political Ecology, Blackwell.

Rocheleau DE (2015a) Roots, rhizomes, networks and territories: reimagining pattern and power in political ecologies. In: Bryant RL (ed.) The International Handbook of Political Ecology, Edward Elgar, UK-USA, pp 70-89.

Rocheleau DE (2015b) Networked, rooted and territorial: green grabbing and resistance in Chiapas. The Journal of Peasant Studies 42:695-723.

Rojas GJC (2012) Conflictos ambientales por medidas de mitigación al cambio climático en territorio Wayuu: el Parque Eólico Jepirachi, 1999-2011, Colombia. Tesis de Magister en Medio Ambiente y Desarrollo. Universidad Nacional de Colombia-Instituto de Estudios Ambientales. Colombia.

Sawyer S (2004) Crude Chronicles: Indigenous Politics, Multinational Oil, and Neoliberalism in Ecuador. Duke University Press.

Scheidel A, Sorman A (2012) Energy transitions and the global land rush: ultimate drivers and persistent consequences. Global Environmental Change 22: 588-595 
Scheidel A, Temper L, Demaria F, Martinez-Alier J (this feature). Ecological distribution conflicts as forces for sustainability: an overview and conceptual framework. Sustainability Science, this feature.

Schlosberg D (2013) Theorising environmental justice: the expanding sphere of a discourse. Environmental Politics 22:37-55

Scoones I (2016) The Politics of Sustainability and Development. Annual Review of Environment and Resources 41:293-319

Smil V (2008) Energy in Nature and Society: General Energetics of Complex Systems. The MIT Press, Cambridge.

Smil V (2016) What I See When I See a Wind Turbine. IEEE Spectrum. Available at: http://www.vaclavsmil.com/wp-content/uploads/15.WINDTURBINE.pdf

Smith E, Klick H (2007) Explaining NIMBY Opposition to Wind Power. Annual Meeting of the American Political Science Association, Boston. Available at:

$\underline{\text { http://www.polsci.ucsb.edu/faculty/smith/wind.pdf }}$

Sovacool B, Dworkin MH (2015) Energy justice: Conceptual insights and practical applications. Applied Energy $142(2015)$ 435-444

Špirić J (2017) Ecological distribution conflicts and sustainability: lessons from the post-socialist European semi-periphery. Sustainability Science, this feature: 1-16.

Swyngedouw E (2010) Apocalypse Forever? Post-political Populism and the Spectre of Climate Change. Theory, Culture \& Society 27: 213-232 
Swyngedouw E (2011) Whose Environment? The end of nature, climate change and the process of postpolitization. Ambiente \& Sociedade XIV:69 -87

Szarka J (2007) Wind power in Europe: politics, business and society. Palgrave, New York.

Temper L, Del Bene D, Martinez-Alier J (2015) Mapping the Frontiers and Frontlines of Environmental Justice: The EJatlas. Journal of Political Ecology 22: 255-278.

Thayer RL, Freeman C (1987) 'Altamont: public perceptions of a wind energy landscape'. Landscape and Urban Planning 14: 379-398.

Thayer RL, Hansen H (1991) Wind Farm Siting Conflicts in California: Implications for Energy Policy. Center for Design Research, University of California, California.

Toke D, Strachan PA (2006) Ecological modernization and wind power in the UK. European Environment 16:155-166.

Trainer T (2014) Some inconvenient theses. Energy Policy 64:168-174

Walker G (2009) Globalizing environmental justice: the geography and politics of frame contextualization and evolution. Global Social Policy 9:355-382

Weale A (1992) New Politics of Pollution. Manchester University Press, Manchester

Wolsink M (2000) Wind power and the NIMBY-myth: institutional capacity and the limited significance. Renewable Energy 21:40-64. 
Yenneti K, Day R, Golubchikov O (2016) Spatial justice and the land politics of renewables: Dispossessing vulnerable communities through solar energy mega-projects. Geoforum 76: 90-99

Zografos C, Martinez-Alier J (2009) The politics of landscape value: a case study of wind farm conflict in rural Catalonia. Environment and Planning 41: 1726-1744 